Article

\title{
Gwendolyn Brooks and the Legacies of Architectural Modernity
}

\author{
Jo Gill(1) \\ Department of English, University of Exeter, Exeter EX4 4QH, UK; j.r.gill@exeter.ac.uk
}

Received: 2 September 2019; Accepted: 2 October 2019; Published: 22 October 2019

check for updates

\begin{abstract}
This essay reads the work of poet, Gwendolyn Brooks, in terms of its critical engagement with the architectural modernity of her home city, Chicago. Taking her poetry from $A$ Street in Bronzeville (1945) through to the 1968 collection, In the Mecca, as a primary focus, the essay traces the significance of Chicago style architecture on Brooks' aesthetic. It was in Chicago that some of the first tall office buildings were designed; it was here that structural steel and glass were first used to distinctive architectural effect, and it was here, in 1893, that the World's Columbian Exposition was held-an event that, for better or worse, was to shape American architecture well into the twentieth century. Brooks' poetry is alert to this history, attuned to contemporary debates about urban design and sensitive to architectural experience and affect. This context informs and shapes her work in often unexpected ways. Her approach is often oblique (registered in metaphor, style, and voice) but nevertheless incisive in its rendering of the relationship between architecture, modernity and power.
\end{abstract}

Keywords: Gwendolyn Brooks; architecture; modernity; Chicago

This essay reads the work of poet, Gwendolyn Brooks (1917-2000), in terms of its engagement with the architectural modernity of her home city, Chicago. It was in Chicago that some of the first tall office buildings were designed; it was here that structural steel and glass were first used to distinctive architectural effect, and it was here, in 1893, that the World's Columbian Exposition, or Chicago World Fair, was held-an event that, for better or worse, was to shape American architecture well into the twentieth century. Brooks' approach to this legacy is often oblique and her rendering of the everyday architectural environment proceeds primarily through the subtleties of structure, metaphor, style and voice. Nevertheless, the contemporary architectural context is everywhere present. It mattered to Brooks and it informs and shapes poems from A Street in Bronzeville (1945) through Annie Allen (1949) to In the Mecca (1968), providing an important foundation for her emerging politics and her distinctive aesthetic. By reading Brooks through the frame of Chicago architecture (and by reading Chicago architecture through Brooks' lens) we can see how the specificity of the contemporary built environment inflected lived experience and its poetic representation, exposing new layers of meaning and exemplifying Brooks' stature as an acute cultural commentator.

In this essay, I do a number of key things. I trace the history of architecture in Chicago-which is also, as will become clear, the history of racial segregation-and I show how Brooks evokes, or better still, exposes what this history means to black citizens. I offer a reading of her work which is attuned to the ways in which architecture is inflected in poetry-often in subtle or circumspect ways. ${ }^{1}$ With Adrienne Brown's recent The Black Skyscraper: Architecture and the Perception of Race in mind, I further reflect on Brooks' experience of architectural innovation. Brown's point is that the rise of modern architecture-heralded and thereafter epitomized by Chicago style-was predicated on "processes of

1 My emphasis on architectural detail provides a different focus to, for example, Courtney Thorsson's reading of "Gwendolyn Brooks' Black Aesthetic of the Domestic" (Thorsson 2015). 
racial perception and apprehension" (Brown 2017, p. 3). Specifically, skyscraper architecture (born in Chicago) compromised or "disrupted" accepted hierarchies of race and power; the view from the top rendered the subject below in miniature and as a powerless black dot, thereby problematizing whiteness at precisely the moment when whiteness was felt to be under threat (Brown 2017, p. 22). Brooks' poetry, I propose, traces the ways in which black subjectivity is negotiated in such a context and provides an important perspective on the relationship between architecture, modernity, race and power.

\section{Chicago Architecture}

Brooks' Chicago is a city of architectural innovation. In the late nineteenth century it was the crucible and testbed for architects and engineers such as John Wellborn Root, Dankmar Adler, Daniel Burnham and Louis Sullivan, and in the early twentieth century, of a new generation of moderns, including Frank Lloyd Wright and Mies van der Rohe. ${ }^{2}$ The first group pioneered the use of structural metal frames, for example in Root's Monadnock Building of 1888-92 and Root and Burnham's Masonic Temple of 1890-92. ${ }^{3}$ Assisted by innovations such as Bessemer steel (mass-produced, economical and load-bearing) these architects were successively able to build higher, to open out a building's interior and to broaden window apertures thereby maximizing natural light and, of course, freeing up more space for rent. Other new technologies, including electric lighting and elevators, further coincided to make it suddenly possible to build tall, robust, usable and financially viable structures. The skyscraper, soon to be regarded as the defining feature of urban American modernity, was born. More broadly, and as a consequence of these and related developments, what we now identify as "modern" architecture-tall buildings, open plan spaces, clean lines, and the use of steel, glass and other light, transparent or reflective materials-also began to emerge, as characterised by the "silver" and "bright glass" of Chicago's Michigan Avenue (Brooks 1993, p. 47).

Chicago at the turn-of-the century was exactly the place to make one's name as an architect. Originally located on ancient Potawatomi Indian lands at the point where goods coming from the north via Lake Michigan could be transferred via the Des Plaines River to the Mississippi (Dyja 2013, p. xxii), the city grew rapidly—sustained in part by the development of the railways—until by 1871, it covered half a mile and had a population of some 300,000 (Algren 2011, p. 110). In October of that year, the Great Fire burned out most of the city's infrastructure, inadvertently providing a clean slate for investors, developers and architects. At the same time, the transition across America away from agriculture and towards manufacturing, and population shifts including the post-Civil War move north of African American workers, generated a thriving economy and an urgent need for industrial premises, housing and infrastructure. Chicago from the outset was open to, indeed depended on, the spirit of invention. As Thomas Dyja notes in his compelling account of the city's growth, Chicago regarded itself for some considerable time as America's premier city.

The rush to develop was largely predicated on the labour of black and ethnic workers and, particularly in the case of black communities, on their segregation. ${ }^{4}$ We see something of the different, and hitherto occluded, experience of these groups in fellow Chicago writer, Carl Sandburg's, poems "Chicago" and "The People, Yes" (Sandburg 2003, pp. 3, 437-617). As Chicago's great new buildings emerged and as the city became more and more crowded, prejudice against black migrants pushed them into certain restricted areas on the city's South Side, the so-called "Black Belt" or, more affirmatively, "Bronzeville," as per the title of Brooks' first collection. In a 1969 interview, she recalled: "I started out talking about Bronzeville, but 'Bronzeville's' almost meaningless by now, I suppose, since Bronzeville has spread and spread all over. Bronzeville, incidentally, was not my own title. That was invented by the

2 For an idiosyncratic account of the period, see Louis Sullivan's Autobiography of an Idea (1956) and for a broader view of the history of modern American architecture, see (Giedion 1967, Space, Time and Architecture) and (Waldheim and Ray 2005, Chicago Architecture).

3 On the Masonic Lodge, see (Wolner 2005).

4 For an early and influential account of this history, see (Drake and Cayton 1945, Black Metropolis). 
Chicago Defender long, long ago to refer to the then black area" (Brooks 1972, p. 160). The emergence of improved transport links to areas outside the city subsequently fostered the growth of the suburbs and the phenomenon which became known as white flight. Brooks' "Beverley Hills, Chicago," discussed later, reflects on these circumstances while "The Ballad of Rudolph Reed" from her 1960 collection, The Bean Eaters, traces the violent repercussions for a black family that seeks a home "in a street of bitter white" (Brooks 1987, p. 377). ${ }^{5}$ At the same time as white suburbs were expanding, urban housing was subject to onerous restrictive covenants and other discriminatory lending practices which meant that black citizens were denied access to any but the poorest and meanest of areas, or what Brooks in Maud Martha calls the "unhandsome gray and decay of the double-apartment buildings" (Brooks 1993, p. 5). ${ }^{6}$

As I will argue later, these larger processes are crystalized—and critiqued —in a number of Brooks' poems, most notably, "kitchenette building" (from A Street in Bronzeville) and "In the Mecca" from the collection of that name. Of kitchenettes, as Rashad Shabazz notes, they "were the place and mechanism that enabled blacks to be packed into the Black Belt. Through their tight and incommodious geography, these one-room shacks jammed with people were an assault on black dignity and a physical reminder of containment" (Shabazz 2015, p. 34). Residents of the Mecca building and the other kitchenettes that feature in Brooks' poetry were living Louis Sullivan's influential architectural truism that "form ever follows function" (Sullivan 1947, p. 208; Sullivan 1956, pp. 258, 290). What I mean by this is that if the "function" is perceived by a powerful white culture to be the provision of barely adequate housing for black citizens, then it becomes possible for the "form" of that housing—undersized rooms, decaying infrastructure- to take hold. The adage was fundamental to the development of modern American architecture. It is not a phrase that Brooks ever cites; nevertheless, her poetry exposes and critiques the principle and its consequences.

At the same time as black residents were confined to particular spaces, the move in modern architecture, certainly from the 1930s onwards with advances in technology and new ideas from Europe, was towards the further opening out of space. In the work of Chicago architect, Frank Lloyd Wright, for example (with which Brooks was evidently familiar-see the note in her memoir, Report from Part Two, about performing a reading at a home of his design (Brooks 1996, p. 98)) we find a celebration of open spaces, horizontal lines, a lateral and expansive vision and the removal of boundaries. Interviewed by Time magazine, Wright reflects "I was working towards the elimination of the wall [ ... ] as a means of opening up space" (Usonian Architect 1938, p. 30); it's an important point because so much of Brooks' work is about walls, and the effect these have on black citizens. Another way of putting this is to say that Brooks' work offers a counter-narrative of architectural modernity—or a view of its effects when seen from a hitherto (and in many ways deliberately and structurally) obscured perspective. When Wright proceeds to rationalize his architectural vision as a riposte to the "crowding" which he saw as a characteristic of late nineteenth-century Chicago, and as fundamentally democratic in intent (he wanted to deliver that "sense of space as should belong to a free people" and to open "a new world of thought that would certainly tear down the old world completely" (Wright 1954, pp. 14, 21, 22)), we can see both how his aspirations might speak to the conditions of life in black Chicago but also how, fundamentally, he failed, or stopped short, of making that connection. If Wright's vision is of "a freedom of space [ ... ] that was quintessentially modern" (Levine 1996, p. 57), and if black citizens are denied access to that space, are they thereby rendered "unmodern"? Brooks reads the material conditions of her subjects in terms that engage with this abstract rhetoric of space, freedom, lightness

5 Unless otherwise indicated, quotations from Brooks' poetry are taken from her 1987 collected volume, Blacks. I have replicated her choices with regards to the capitalization of certain titles, e.g., "kitchenette building," discussed later.

6 For more on the history of the suburbs see Jackson (1985) Crabgrass Frontier and the essays in The New Suburban History (Kruse and Sugrue 2006). It is worth remembering the case of Carl Hansberry (father of Brooks' contemporary, the playwright Lorraine Hansberry). In 1938, Hansberry's father, a Chicago property developer who had acquired his wealth by sub-dividing units in black areas, was confronted by a "restrictive covenant prohibiting nonwhite residence" when he tried to move his family into the predominantly white Washington Park area (Jurca 2001, p. 216, n. 50). 
and modernity. With Adrienne Brown's work in mind, I suggest that her poems "illustrate the ways the built environment affects the perceptual and affective life of race" (Brown 2017, p. 30).

\section{Bronzeville}

Brooks' first collection, A Street in Bronzeville, is firmly located in the distinctive architectural environment of mid-century Chicago and has, I will argue, a particular architectural register. "The old-marrieds," the first poem in the title-poem sequence that opens the collection, places its subjects in the "crowding darkness" (Brooks 1987, p. 19). This is at one and the same time, an urban street scene akin to those that we see in Brooks' modernist predecessors (T.S. Eliot and Hart Crane, for example) and, more importantly, a physical and material location. Black housing in Chicago was typically over-crowded, poorly lit (formerly spacious departments were subdivided to form smaller "kitchenette" units) and badly maintained (Shabazz 2015, p. 36). The "crowding darkness" thus has a specifically architectural meaning. The oppressive nature of this environment is evident from the poem's first word, "But," and from the sense of denial and exclusion apparent in the subjects' (self?) silencing: "not a word did they say." The poem tries hard to read this context as a possible site of loving affection, hence allusions to "pretty-coated birds," to "lovers," glimpsed up side streets, and to the auspicious timeframe (a midnight in May). Nevertheless, as line two cautions, and as the repetition in the final line of the sombre initial phrase makes clear, the "crowding darkness" continues to prevent intimacy, paradoxically denying the "old-marrieds" the chance of closeness: "not a word did they say." This initial and terminal repetition, coupled with the flat rhyme scheme (aabbaa) produces a clamped and claustrophobic effect commensurate with the built surroundings.

A similar sense of constraint informs the next poem in the collection, "kitchenette building" (Brooks 1987, p. 20). Again, a restrictive architectural environment seems to curtail the subject's experience, opportunities and sense of self. Again, the speaker's self-restraint, revealed in the cautious, qualifying "But" at the beginning of stanza two and the persistent negations-"not well! Not for a minute" (final stanza) - tell us much about the necessary accommodations she must make in order to tolerate such a setting. "Kitchenette building" describes conditions in the multiple multi-occupancy buildings of Chicago's South Side. As a young married woman in 1939, Brooks moved into the first of a succession of such apartments. Here, as her biographer George Kent notes, she "felt the cramped dreariness, the increep of bleakness" (Kent 1990, p. 47). This unsavoury environment dehumanizes its residents; "we are things," as line one of "kitchenette building" explains. "We" are subject to the oxymoronic "involuntary plan" - where "plan" means someone else's dictates and, more broadly, the architectural and urban development policies then determining the size and shape of the city. We are "grayed in, and gray," or sapped of light and space and thus of life.

Chapter 15, "The Kitchenette," from Brooks' 1951 novel, Maud Martha, further expands on these conditions - on the rats, the roaches, the atmosphere: "The color was gray, and the smell and sound had taken on a suggestion of the properties of color, and impressed one as gray too" (Brooks 1993, p. 63). "Gray" functions as a metonym for black experience in a dark, decaying environment. In Maud Martha, again: "there was a whole lot of grayness there" (Brooks 1993, p. 64). In emphasizing the grayness of the black experience in this architectural context, Brooks signals that it is the black citizens' status in relation to whiteness that determines the conditions in which they must live; whiteness is seen to entitle the bearer to superior accommodation whereas "grayness" and/or black identity ("the properties of color") denies one that right. Race, in effect, is doubly-marked. First by the context-after all, it is only black citizens in this period who are living in this way-and then by explicit reference. The point exemplifies Brown's argument that during this period race had to be carefully delineated in order to avoid the disorientating, vertiginous or "giddy" effects of the new architectural environment; in line two of Brooks' poem, "'Dream' makes a giddy sound, not/strong."

Amidst the grayness, the poem's speaker must find other ways of evoking the particular conditions of the "kitchenette building": through smell ("onion fumes," "garbage"), taste ("fried potatoes") and sound (an "aria"). That her speaker can hear an "aria" is a pointed riposte to received views about 
appropriate places for (and voices of) poetry, for example, to Edmund Wilson's view, writing in Vanity Fair, that the Chicago environment "does not naturally lend itself to the music of majestic verse" (Wilson 1920, p. 66). Indeed, the really interesting thing about this poem is the tension that it generates between the pervasive, soul-destroying atmosphere of life in the kitchenette buildings of Chicago and the refusal on the part of the speaker to let that environment, or this architecture, control her aspirations. Her "dream," introduced at the beginning of stanza two and suspended through to the end of the next stanza, although tentative and qualified ("could a dream send up [?]"), nevertheless survives. The syntax of these two central stanzas, with the delayed performative "let it begin" at the end of stanza three which answers the question about the dream, keeps open the possibility of change, or of living beyond these current circumstances. The final clause in the poem, referring ostensibly to lukewarm bath water (and her "hope to get in it") nevertheless leaves a vestige of "hope" alive. Brooks is weaving a careful path through a set of circumstances which, although they must be exposed, cannot be taken as wholly determining black residents' lived experience. In this respect, too, Brooks is engaging with a set of contemporary debates about architectural determinism-defined as a preoccupation with the effects of buildings, places and living conditions on the manners and morals of residents, or a perception, that "buildings themselves were [ ... ] acting upon people, or social material" (Forty 2000, p. 174). This was a particular bugbear of privileged commentators when concerned about the lower classes and black and ethnic groups. "We" may be treated as "things," the poem notes, "We" may be subject to someone else's "plan." Nevertheless, "we" can mediate our own environment (hence "anticipate a message" in stanza three) and, through our "dream[s]" and "hope[s]," settle our own interpretation and intent.

It is characteristic of Brooks' style, and crucial to its effect, that she articulates or names these conditions in order to recast or deny their influence. In Maud Martha, for instance, she describes the dirty, decaying conditions in which the "tiny lives" of the children are played out, precisely so as to demonstrate that their own colour, and noise and energy exceed-erase-their immediate circumstances: "cramp, inhibition, choke-they did not trouble themselves about these" (Brooks 1993, p. 5). Similarly, in "the independent man" from A Street in Bronzeville, the addressee seems at first to be confined to a "tiny life/In one room or in two rooms or in three" (Brooks 1987, p. 33). But the form and tone of the poem with its rhetorical flourishes and buoyant and expansive thinking, undermine that premise. No one, it transpires, not "any woman," not even a "wife," and certainly not the strictures of the architectural environment, can curtail his spirit. Turning back to "the old-marrieds," too, we should perhaps modify the view that circumstances render Brooks' subjects entirely mute. Instead, what we see in these and other poems is her speakers negotiating or entering into a dialogue with architectural modernity. There is a refusal in other words to be passive, to live the oppression that the architecture seems to impose, and there is a commitment instead to speaking from and of the nuances of what architectural critic Sophie Psarra terms "embodied experience" (Psarra 2009, p. 13).

Brooks invokes the aesthetics of Chicago style architecture without necessarily explicitly naming buildings, drawing on the distinctive look as a way of reflecting on (black) identity, aspiration and agency. "Hunchback girl: she thinks of heaven," also from A Street in Bronzeville, takes the emphatic "verticality" which is characteristic of the new urban architecture (Bender 2002, p. 51) as an implicit backdrop to, and stimulus for, the first-person speaker's upward gaze. "My father," the poem opens, heaven must be "a blue place/And straight. Right. Regular" (Brooks 1987, p. 27). Perfection, taking its cue from the contemporary architectural ideal, must be clear ("blue") and as "regular" and true as the Chicago grid and the steel-framed buildings that had arisen post-1871 from the city's swampy ground. Here, anything "crooked" is to be spurned; the straightness of the speaker's aim and her desire for perfection are rendered in an inescapably architectural metaphor-in the embrace of a "love that runs without crookedness/Along its crooked corridors." Heaven, she goes on to insist, is "a planned place surely" (where, again, the plan refers both to a sense of order and to contemporary urban planning). Other poems from A Street in Bronzeville, as we have seen, portray disordered, chaotic, or "crooked" environments. "Hunchback girl" shows us the body itself distorted by its surroundings. 
Likewise, in "the birth in a narrow room" from her next collection, Annie Allen, the labouring woman exclaims: "'How pinchy is my room! how can I breathe!'” (Brooks 1971, p. 3). When the hunchback girl thinks of heaven, she thinks of a place distinguished in terms that reflect the architectural idiom of the day, in straight lines and planes. This is a "planned" spatial order which, in her imagination, sets right the social and affective disorder (the crookedness) of her reality. Free of her body and of the "crooked corridors" that constrain her, she will, in the words of the penultimate line, "walk straightly through most proper halls" (Brooks 1987, p. 27).

Similarly, in the slightly earlier poem, "southeast corner," the "Madam's" final resting place, "out at Lincoln" is marked by a monument the shape and look of which draws its power from contemporary skyscraper architecture (Brooks 1987, p. 23). Here, "the thickest, tallest monument/Cuts grandly the air." The conceit of "Southeast Corner" is that the "Madam," like the skyscraper magnates of the era (Rockefeller, Woolworth et al) converted her wealth into a memorial made of "cool hard steel." Architecture thus becomes a metaphor for a certain power and a particular legacy. In both cases, what we also see is the speakers, at last, staking a claim to a particular space. To fully understand the implications of this, we need to remind ourselves both of the segregated nature of urban Chicago and of the exponential overcrowding that pertained within the Black Belt (the black population of Chicago "more than doubled in the 1910s, from 44,103 to 109,458" (Bluestone 1998, p. 391)). The irony of both poems is that the black female speakers can only lay claim to this space in fantasy (the dream of heaven) or in death (the graveyard plot).

Another poem from the same period, "a song in the front yard," makes a more cautious claim. "A song" is ostensibly, and allegorically, about a good girl's desire to try a little of life on the wild side, or to give in to the temptations of a "good time" (Brooks 1987, p. 28). But this aspiration, again, is realized in terms of the architectural surroundings and, specifically, of restrictions on space. As the poem's opening lines explain: "I've stayed in the front yard all my life./I want a peek at the back." At issue in each of these cases are black Chicagoans' rights to particular spaces. In the architecture of the period, as we saw with respect to Frank Lloyd Wright, space defines modernity (Giedion notes of early twentieth-century architecture, that it was intent on "organizing space in ways that gave form to contemporary feelings" (Giedion 1967, p. 26)) and access to space is a sign of democracy. A lack of space is thereby unmodern, and the denial of space to black citizens is a covert way of refusing the rights and privileges of a democratic society.

\section{Plain Style}

I have spoken already about the aesthetic of plainness that shaped modern architecture and the model of clean lines that characterized Chicago style (Wallace Stevens commented that "modernity is so Chicagoan, so plain" (Stevens 1977, p. 53)). In Brooks' work, as in contemporary architectural discourse more widely, this clean, modern ideal masks a persistent tension whereby the pull of the past, or of traditional styles, materials and ornament, continues to exert an influence. The architectural debate mirrors a broader cultural and political dialectic in the interwar period (and, arguably, beyond) of tradition versus innovation; conservatism versus change; old world versus new; the past versus the future. Brooks engages with these discussions and draws on specifically architectural metaphors in a number of poems. In "The Sundays of Satin-Legs Smith," for example, the much-lauded Satin-Legs is seen rising in the morning and preparing to present himself to the world, "That no performance may be plain or vain" (Brooks 1987, p. 42, stanza three). In the lengthy fifth stanza, we see him working consciously, if quizzically, on his planned appearance for the day. Should he bathe in lavender or pine, lilies or roses? Which ornament, in other words, will best express his identity and mood? In invoking flower motifs, Brooks is replicating the use of foliage as an architectural embellishment. Bluestone explains that the interior balconies in Chicago's Mecca Building were "heavily foliated" (Bluestone 1998, p. 384) while William Hansell notes Brooks' use in that poem of flowers seen withering on the vine (Hansell 1974, p. 203). There is a hierarchy of values-and of power-here. For all that Satin-Legs fantasizes about draping himself in "gentle garden in the best/of taste" he is forced to 
remember that his true locus is "alleys, garbage pails." The mode of representation that he seeks is out of reach. Denied floral representation (in stanza six, "No! He has not a flower to his name"), Satin-Legs must find alternative means of self-projection, perhaps through clothes-although the ermine and diamonds of royalty that he yearns for must needs be replaced with less precious materials.

Here we come to the complex crux of this highly ambiguous poem. Just as Satin-Legs must choose the best mode of self-representation, we are asked to weigh up relative values of ornament and simplicity, richness and plainness, and finally to assess the innate beauty of Satin-Legs' own form with his "neat curve" and "angularity" and his "technique of a variegated grace." Courtney Thorsson notes, with this poem as an example, that "the notion that black is beautiful saturates Brooks' poetry" (Thorsson 2015, p. 154). In this look we find, as the next stanza proceeds, "all his sculpture and his art/and all his architectural design." And we are asked to choose between this simple aesthetic-the angles, curves and grace that are emblematic of modern, unadorned style-and an alternative, formed of "marble, complicated stone." It's a superb manoeuvre; Brooks sets up (traditional) ornament as the aspiration but shows us that the true ideal—one that actually is within Satin-Legs' grasp-is of (modern) simplicity. At the same time, the poem leaves open a question about why Satin-Legs should have to reconcile himself to plainness when the culture that surrounds him continues to value ostentatious display. Ornament in this context, or the embrace of embellishment, becomes a form of self-care to which he is entitled even if some would, apparently, urge him to "think with horror of baroque/Rococo." Thus, even if contemporary architecture is turning to embrace the plain and unadorned, residual value attaches to the highly worked, and Satin-Legs should not be denied this rich, decorative pleasure. That the architectural context is, at least in part, at play here is apparent in stanza thirteen with its brutal reminder that, his ideals notwithstanding, a landscape of "broken windows" and "sore avenues" is his lot.

If black spaces are literally and metaphorically cramped and constrained, white spaces, by contrast are imbued with light. Light in this context signals architectural modernity; it suggests the new, the free, the liberated and unconstrained. We recall the lifeless, lightless "gray" of "kitchenette building." In "Beverley Hills, Chicago" from Annie Allen, Brooks works with multiple gradations of light and shade in tracing differential access to particular loci, thus imbuing the poem and its context with connotations both architectural and racial. The poem offers a critical commentary on the rise of the suburbs and of so-called white flight. "Beverley Hills, Chicago" is the eighth in the fifteen-poem sequence, "The Womanhood." It opens with an epigraph from fellow poet, E.M. Price, "'and the people live till they have white hair"' (Brooks 1971, pp. 48-49). The line establishes the theme of dignity, longevity and racial difference that sustains the rest of the poem and the tone of longing that persists throughout. It also introduces one end of the spectrum or colour palette that the rest of the poem proceeds to develop. More than this, it tacitly registers something of the wider context-the contemporary housing crisis-which lies behind the growth of the (white) suburbs and the (black) speaker's visit to it.

"Beverley Hills, Chicago" describes the speaker's drive through this privileged environment. The "people" who live here, we know already, are associated with whiteness and with the luxury of a long and leisured life. In the first line of the poem, shades of brown appear in the image of the "dry brown" leaves heard "coughing" beneath the homeowners' feet. It is a metaphor which both diminishes the black subjects and identifies them with some form of malaise. Moreover, it renders them voiceless (they can cough but they can't speak clearly). This theme is echoed in the muted tones throughout the poem and reinforced in the final line where, silenced by the injustice of what they have just seen, the visitors' "voices are a little gruff." From "brown" we move in line three to the suburbanites' lighter "golden gardens." Later again, in stanza three, the setting is rendered in shades of "everlasting gold" where the residents take tea against a "gold-flecked backdrop." By contrast, the speaker and her peers are associated with "little black dots," sour lemons, and noisy and cramped ("sweatingest") apartments (stanzas three and four). In carefully measured tones, marked by exaggerated courtesy and emphatic - if not entirely successful—denials, the speaker insists; "Nobody hates these people" (stanza six). But she cannot let go of a sense of the injustice by which "these people" in this place with 
this power have so much when we "have not enough." The smooth, restrained surface notwithstanding, it is clear in the final two stanzas that something is awry (or "crooked" to return to "hunchback girl: she thinks of heaven"), morally, politically, and spatially. "It is only natural" as the poem concludes, that the speaker should expect something different.

"Beverley Hills, Chicago" is more, though, than simply a complaint or lamentation. Just as "kitchenette building" unexpectedly discovers a voice, or an "aria," thus revealing a hitherto overlooked complexity and quality of experience, so too this suburban poem shows us something we may not have expected to find. It is a poem that proceeds discreetly, with so many subtleties and denials that we might miss its substantial point about the unregistered presence of black people within this suburban enclave; they are, after all, here all the time-as gardeners (sweeping up the "brown leaves"), as tea-makers, as burnishers of golden ornaments, as layers out of corpses (see stanza five). This is a poem about denial (hence the repetition of "Nobody" and "not"), constraint and multiple forms of injustice which are experienced at a personal level and in terms of restricted access to particular architectural spaces. ${ }^{7}$ But it is also a poem that exerts control over the situation and that covertly sets an important alternative narrative of experience.

A counterpart poem, "The Lovers of the Poor," from the slightly later collection The Bean Eaters, is even more explicit in its comparison of suburban luxury and urban grime (Brooks 1987, pp. 349-52). Again, the poem opens with a pattern of light and shade as though to replicate the racial dimension. Again, a succession of emphatic, often rhetorical, negatives (this is "Not Lake Forest, Glencoe./Nothing is sturdy, nothing is majestic" (lines 41-42)) is used to bring into view the thing ostensibly being occluded. This time the implied speaker, or the focalization, is through the eyes of white visitors to a black tenement, the "Ladies from the Ladies' Betterment League" who have made it their business to visit "the worthy poor." In both poems, defamiliarisation is key to the exposure of architectural and social difference. The league visitors cannot help but exclaim at the "Squalor!" and at "This sick four-story hulk, this fibre/With fissures everywhere" (lines 74-75; note the metaphors of disease). And it is a short step from the ladies noting this to Brooks invoking a larger and crucial context-the "puzzled wreckage/Of the middle passage" (lines 70-80). The line refers both to the narrow confines of the building's corridors and, pointedly, to the history of slavery and racial oppression that lies behind what the ladies see. Nevertheless, the poem closes with an assertion of the perspective of the black residents and with now-unguarded contempt for the white women as, in rising panic (hence the transfer of their hysteria onto the building itself, emphasized by the claustrophobic rhyme of "hall" and "wall") they flee:

Keeping their scented bodies in the center

Of the hall as they walk down the hysterical hall,

They allow their lovely skirts to graze no wall[.]

\section{In the Mecca}

The unnamed building that the ladies flee at the end of "The Lovers of the Poor" resembles Chicago's famous Mecca Building, also the subject of the title poem of Brooks' 1968 collection. The Mecca Building, labelled the "strangest place in Chicago" in the December 1950 feature by John Bartlow Martin in Harper's magazine that Brooks takes as her epigraph, was built in 1891. Designed as an apartment building by Willoughby J. Edbrooke and Franklin Pierce Burnham, and originally featuring 98 large flats, the building was, in its moment, a model of architectural innovation and, with its use of light, open space and the latest materials, of Chicago style. Bluestone notes that it was constructed as part of "the building boom that accompanied the 1893 World's Columbia Exposition"

7 This poem writes back to a body of work on the suburbs and anticipates Langston Hughes's 1967 poem, "Suburban Evening." For more on suburban poetry in general, and Hughes's poem in particular, see (Gill 2013). 
(Bluestone 1998, p. 388). He further records that the Mecca was designed with two extensive wings, featuring "an enormous interior skylit atrium [ . . ] ] each one measuring 33 by 170 feet. In each wing a ground-story lobby, stairs and heavily foliated ornamental balconies, cantilevered from the atrium's walls, provided access to the individual apartments" (Bluestone 1998, p. 384). In this way, the lives of the residents were made visible even as the separate apartments pretended to the kind of cozy intimacy more typically associated in the period with the individual family home.

In 1900, the Mecca was home to 365 people in 107 units most of whom were working or lower-middle class, and all of whom were white. Some twenty year later, with the rise in Chicago's black population noted earlier, and their restriction to certain areas, there were 510 residents, most of whom were black, in 148 units. By the early 1940s, the period when the poem is set, the Mecca housed more than 1000 crammed into multiple sub-divided units, each in poor repair after decades of neglect at the hands of a succession of absentee landlords including, latterly, and as I'll explain later, the Illinois Institute of Technology, or IIT (Bluestone 1998, pp. 390, 394). Brooks had briefly worked in the building as "secretary to a spiritual advisor who sold lucky numbers and 'magic potions'" (Brooks 1996, p. 150). By 1958, when she first drafted the poem, originally as a novel (Melhem 1987, p. 153), the Mecca was gone, demolished some 8 years earlier, and against considerable resistance from the community who lived there, to make way for the development of the IIT, including for buildings designed by acclaimed modernist architect, Mies van der Rohe. Mies was an important figure in contemporary, and specifically, "international style" architecture. ${ }^{8}$ He left Hitler's Germany in 1938, arriving in Chicago to take up commissions for the city's Armour Institute and IIT. For reasons of space, I won't rehearse the long and fraught history of this event (although Dyja provides a good overview). ${ }^{9}$ I would note, though, that just as Brooks' earlier poems make tacit, but nevertheless critical (in both senses of the word) reference to the architectural history that determined the particular places in which black Chicagoans were permitted to live and work, so too "In the Mecca," tells a story, albeit sometimes obliquely, of the rise of modernity. Melhem suggests of the poem that, "in the course of Mrs. Sallie's search for her daughter, Brooks sketches a representative number of tenants and addresses a broad range of contemporary and philosophical subjects" (Melhem 1987, p. 159) to which I would add that there is also a crucial architectural concern. If black communities in Chicago are restricted to the Black Belt and crammed into crumbling buildings like the Mecca, what happens when even these spaces are denied to them?

The plight of the Mecca Building exemplifies the larger architectural (and racially segregated) history of Chicago. The IIT had been acquiring neighbouring land and razing buildings to enable its own expansion across the 1930s; it was left the Mecca in a will and thus became, in Dyja's words, the "'reluctant landlord' of some one thousand tenants." The Institution's "opinion of them," he goes on to say, "is evident in a 1940 map showing the status of acquisitions-the corner where the Mecca stands is listed as 'vacant'" (Dyja 2013, p. 17). For the decade that IIT owned the building, the institute neglected to improve or even maintain it, apparently in the expectation that-the current housing shortage notwithstanding - tenants would decide to move out. This is the sorry story that Brooks' poem brings to life. What is apparent is that the conditions of life for Chicago's African American communities are inextricably linked with the larger story of architectural advancement. Brooks is clear about the architectural foundation: in her notes on "Work Proposed for 'In the Mecca"' she explains that her aim is "to touch every note in the life of this block-long block-wide building" and thereby to "capsulize the gist of black humanity in general" (Brooks 1972, p. 190). The loss of amenity, the denial

8 The concept of an "international style" captured some of the changes evident in the early decades of the century as transnational influences, developments in other artistic fields, and innovations in techniques and materials coalesced. A 1932 exhibition at New York's Museum of Modern art, "Modern Architecture: International Exhibition," and the subsequent catalogue The International Style helped disseminate the term. See (Hitchcock and Johnson 1995).

9 See also the essays in (Lambert 2001). 
of the right to occupy certain spaces and to live in a humane way is the price, it seems, to be paid for progress.

The poem traces the trauma of one family and one mother, Mrs. Sallie, as she returns to her home in the Mecca only belatedly to realize that one of her children, the aptly named Perdita, is lost. In seeking this child, she sets off on a hopeless quest through the labyrinth of the building. Her journey in and out of dark corners and up and down precipitous steps and lengths of balcony shows us architecture as lived experience and as reification of her vulnerability, confusion and fear. The building was designed for looking, or as a space of "urban spectacle" (Bluestone 1998, p. 392). Here that capacity is pushed to its limit; the architecture itself has allowed someone to be taken. Its lines of sight have either inured the watchers or have proved to be inadequate-for every clear view, there is an equal and opposite corner of obscurity-thus preventing her discovery. Architecture has failed. It is in this context that the opening stanza, with its reference to an acclaimed proponent of modern architecture, is to be read:

Sit where the light corrupts your face.

Miës Van der Rohe retires from grace.

And the fair fables fall.

(Brooks 1968, p. 5)

Brooks' metaphor of "light" is particularly significant. It recalls "The Ballad of Rudolph Reed" with its exposé of the hegemony of architectural modernity, realized in the "bitter white streets" that violently, murderously, repel him (Brooks 1987, p. 376). She draws on, while also critiquing, the use of light as an important medium in modernist architecture-a tendency which developed from the light-inducing steel structures and horizontal window apertures of turn-of-the-century Chicago style. These opening lines suggest something, to return to Adrienne Brown, about the anxious defence of whiteness in this culture, especially among those who saw the novel perspectives of contemporary architecture as somehow threatening established racial categories. And it sets the whole poem in a broader figurative frame whereby all that is right and good and proper (line two's "fair") is both posited as a virtue and put under question. The fact that "light" here is twinned with corruption and then associated with Mies who, in turn, "retires from" (not "retires in") "grace" suggests that we are in the presence of a fundamental rethinking of the hierarchies of value which might otherwise pertain. In her notes towards the poem, Brooks is clear about the relationship between light and dark: "I wish to present a large variety of personalities against a mosaic of daily affairs, recognizing that the grimmest of these is likely to have a streak or two streaks of sun" (Brooks 1972, p. 189; emphasis original). In line three, where "fair fables fall," there is an aural echo of sables (or blacks) and thus a telling oxymoron (light or "fair" versus dark or sable) and there is a trace of rhyme ("fall"/wall) which speaks to the wider context of containment and suggests, perhaps, that certain walls—of ignorance or prejudice-might be about to "fall." That the "fair fables fall" implies also that Brooks' mission is to expose the stories, or "fables," which would determine our understanding of life in the Mecca. The Harper's article she cites as a lengthy epigraph has been regarded since as perpetuating a highly damaging narrative of black squalor and passivity - a kind of othering which Brooks, as Daniela Kukrechtová indicates, is determined to resist. Light and dark; white and black function in complex and sometimes unexpected ways to structure the poem's meaning.

The architectural framework to this poem of fifty-seven extended stanzas, although skeletal (and thus not explicitly visible) persists throughout, complementing other structuring features. As Karen Jackson Ford argues, "ancient social structures undergird the human architecture of the Mecca building" (Ford 2010, p. 385) while for Kukrechtová, the stanzas "reflect the design of the building, namely the long corridors punctuated by numerous doors" (Kukrechtová 2009, p. 460). We can further trace the architecture in fleeting references to stairs (stanza two); doors and steel (stanza three); to the "threshold" (stanza four) and, later, to windowsills, glass, grilles, gargoyles and so on. In stanza four, where we might expect the oppressive architecture to determine black experience, or subjectivity, we find that 
the subjects themselves mediate or modify their surroundings, hence "Hyena/The striking debutante" who "bursts" free of her "dusty threshold" to become "One of the first and to the tune of hate,/in all the Mecca to paint her hair sun-gold." The moment marks a refusal, akin to that of "Satin-Legs Smith" or the residents of the "kitchenette building" to wholly succumb to the dust and the decay.

Shortly thereafter, we are introduced to Mrs. Sallie and straightaway to her dissatisfaction with her environment; "It is bad, is bad," she observes, of her "sick kitchen." Again the metaphor of light is used to invoke contemporary architecture and specifically the loss of access to certain spaces and amenities: "all my lights are little!" she exclaims. The utterance registers her frustration with her lot in general, with the specificity of her living conditions and with her failure or powerlessness to change them:

'I want to decorate!' But what is that? A

pomade atop a sewage. An offense.

First comes correctness, then embellishment.

(Brooks 1968, p. 8; emphasis original)

Ford suggests that "associating embellishment with the appeasement of suffering, Brooks [...] recruits lyric effects to calm the poem after its storm of sorrows and terrible losses" (Ford 2010, pp. 385-86). More than this, Brooks engages with contemporary debates about relative forms of architectural value - the familiar ornament of traditional styles versus the austere look of the new, epitomized by Mies van der Rohe and other scions of modernity. Just as Satin-Legs Smith did in "The Sundays of Satin-Legs Smith," Mrs. Sallie is defending her right to rich ornamentation, even as she acknowledges that to get the embellishment right, or to achieve the look she desires, there needs first to be a level of order or "correctness." Elsewhere, for example in "A Bronzeville Mother Loiters in Mississippi, Meanwhile, a Mississippi Mother Burns Bacon" from The Bean Eaters, Brooks' poem on the Emmet Till murder, it is the erosion of the decorative surface that signals the rupture in the social fabric beneath. There, the white woman implicated in Till's fate recognizes "with terrible clarity" that "her composition/Had disintegrated" and that "although the pattern prevailed,/The breaks were everywhere" (Brooks 1987, p. 335). Another way of reading the images in both poems is to say that Brooks is conceding that even simplicity (aesthetic "correctness") is an effect which is achieved only by careful work - an insight which stands for this very poem. Its ostensibly straightforward ballad form, its narrative thrust, its cast of characters, all are the fruits of "correctness, then embellishment." The point confirms one of Wright's principles of modern architecture: the idea that ornament should be "integral to building as itself poetry" (Wright 1943, p. 347). What he means by this is that ornament should be structural, or part of the integrity ("correctness") of the design and not something that is applied only superficially.

In the end, as the rest of "In the Mecca" seems to confirm, the aspiration to improve this place is in vain, or comes too late. Yet the final stanzas do revert to some of the decorative or ornamental motifs which Mrs. Sallie has yearned for (roses, singing birds) in order to invoke the possibility of something better and, to return to Martin's Harper's article, "The Strangest Place in Chicago," to give voice to the otherwise silenced. The image of singing birds in particular responds to Martin's closing assertion that as he leaves the Mecca building, he can hear only "unintelligible" words, or "just a human voice, muttering, and it is impossible to tell whether in anger or in joy; it is only sound" (Martin 1950, p. 97). For Brooks, what can be heard is more than "unintelligible [ ... ] sound." It is the echo of Perdita's voice, proclaiming her subjectivity against the odds. As Ford observes, "at the end we hear her song, as the child comes alive for us for the first time" (Ford 2010, p. 386).

Gwendolyn Brooks' poetry from the mid-1940s through to the late 1960s, shows us how contemporary urban architecture looks and feels from an unanticipated and usually overlooked perspective. Where much poetry of the period, for example, Sandburg's “Hats” (Sandburg 2003, p. 160), makes the most of the view of the city from above, Brooks' work shows us the experience of urban architecture from below, from crowded corridors and dark corners, or-as in the case of "Beverley 
Hills, Chicago"-from the outside. This is a body of work that refuses to be overwhelmed by the spectacular buildings that tower above, or to be silenced by the dominant narrative of architectural progress. Brooks offers a different sensibility; one that is highly attuned to contemporary debates and alert to- and critical of-unintended architectural effect.

Funding: Some of the initial research for this paper was funded by a Leverhulme Trust Research Fellowship (RF-2015-313).

Conflicts of Interest: The author declares no conflict of interest.

\section{References}

Algren, Nelson. 2011. Chicago: City on the Make, 5th ed. Chicago: University of Chicago Press. First published 1951. Bender, Thomas. 2002. The Unfinished City: New York and the Metropolitan Idea. New York: The New Press.

Bluestone, Daniel. 1998. Chicago's Mecca Flat Blues. Journal of the Society of Architectural Historians 57: $382-403$. [CrossRef]

Brooks, Gwendolyn. 1971. Annie Allen. Westport: Greenwood Press. First published 1949.

Brooks, Gwendolyn. 1968. In the Mecca. New York: Harper and Row.

Brooks, Gwendolyn. 1972. Report from Part One. Detroit: Broadside Press.

Brooks, Gwendolyn. 1987. Blacks. Chicago: The David Company.

Brooks, Gwendolyn. 1993. Maud Martha. Chicago: Third World Press. First published 1953.

Brooks, Gwendolyn. 1996. Report from Part Two. Chicago: Third World Press.

Brown, Adrienne. 2017. The Black Skyscraper: Architecture and the Perception of Race. Baltimore: Johns Hopkins University Press.

Drake, St. Clair, and Horace R. Cayton. 1945. Black Metropolis: A Study of Negro Life in a Northern City. New York: Harcourt, Brace and Company.

Dyja, Thomas. 2013. The Third Coast: When Chicago Built the American Dream. New York: Penguin.

Ford, Karen Jackson. 2010. The Last Quatrain: Gwendolyn Brooks and the Ends of Ballads. Twentieth-Century Literature 56: 371-95. [CrossRef]

Forty, Adrian. 2000. Words and Buildings: A Vocabulary of Modern Architecture. London: Thames and Hudson.

Giedion, Sigfried. 1967. Space, Time and Architecture: The Growth of a New Tradition, 5th ed. Cambridge: Harvard University Press. First published 1941.

Gill, Jo. 2013. The Poetics of the American Suburbs. New York: Macmillan.

Hansell, William. 1974. Gwendolyn Brooks's 'In the Mecca': A Rebirth into Blackness. Negro American Literature Forum 8: 199-209. [CrossRef]

Hitchcock, Henry-Russell, and Philip Johnson. 1995. The International Style. New York: WW Norton. First published 1932.

Jackson, Kenneth T. 1985. Crabgrass Frontier: The Suburbanization of the United States. New York: Oxford University Press. Jurca, Catherine. 2001. White Diaspora: The Suburb and the Twentieth-Century Novel. Princeton: University of Princeton Press.

Kent, George. 1990. A Life of Gwendolyn Brooks. Lexington: UP Kentucky.

Kruse, Kevin M., and Thomas J. Sugrue, eds. 2006. The New Suburban History. Chicago: University of Chicago Press.

Kukrechtová, Daniela. 2009. The Death and Life of a Chicago Edifice: Gwendolyn Brooks's 'In the Mecca'. African American Review 43: 457-72. [CrossRef]

Lambert, Phyllis, ed. 2001. Mies van der Rohe in America. Montreal: Canadian Centre for Architecture, New York: Whitney Museum of American Art.

Levine, Neil. 1996. The Architecture of Frank Lloyd Wright. Princeton: Princeton University Press.

Martin, John Bartlow. 1950. The Strangest Place in Chicago. Harper's Magazine, December. 86-97.

Melhem, D.H. 1987. Gwendolyn Brooks: Poetry and the Heroic Voice. Lexington: University Press of Kentucky.

Psarra, Sophie. 2009. Architecture and Narrative: The Formation of Space and Cultural Meaning. London: Routledge. Sandburg, Carl. 2003. The Complete Poems of Carl Sandburg. Intro. Archibald MacLeish. New York: Harcourt.

Shabazz, Rashad. 2015. Spatializing Blackness: Architectures of Confinement and Black Masculinity in Chicago. Chicago: University of Illinois Press. 
Stevens, Wallace. 1977. Souvenirs and Prophecies: The Young Wallace Stevens. Edited by Holly Stevens. New York: Alfred A. Knopf.

Sullivan, Louis H. 1947. Kindergarten Chats and Other Writings. New York: Wittenborn. First published 1901.

Sullivan, Louis H. 1956. The Autobiography of an Idea. Foreword Claude Bragdon. New York: Dover. First published 1924. Thorsson, Courtney. 2015. Gwendolyn Brooks' Black Aesthetic of the Domestic. Melus 40: 149-76. [CrossRef] Usonian Architect. 1938, Time, January 17, 29-32.

Waldheim, Charles, and Katerina Rúedi Ray, eds. 2005. Chicago Architecture: Histories, Revisions, Alternatives. Chicago: University of Chicago Press.

Wilson, Edmund. 1920. The Anarchists of Taste. Vanity Fair, November. 65-67.

Wolner, Edward W. 2005. Chicago's Fraternity Temples: The Origins of Skyscraper Rhetoric and the First of the World's Tall Office Buildings. In The American Skyscraper: Cultural Histories. Edited by Roberta Moudry. Cambridge: Cambridge University Press.

Wright, Frank Lloyd. 1943. An Autobiography. New York: Duell, Sloan and Pearce.

Wright, Frank Lloyd. 1954. The Natural House. New York: Horizon.

(C) 2019 by the author. Licensee MDPI, Basel, Switzerland. This article is an open access article distributed under the terms and conditions of the Creative Commons Attribution (CC BY) license (http://creativecommons.org/licenses/by/4.0/). 